\title{
IAMJ
}

INTERNATIONAL

AYURVEDIC

MEDICAL JOURNAL

[ब] 1

Research Article

ISSN: 23205091

Impact Factor: 5.34

\section{A CLINICAL STUDY TO EVALUATE THE EFFICACY OF NASYA WITH SARSHAPA- TAILA IN VISHADA (DEPRESSION)}

\author{
$\underline{\text { Pramod Bhovi }^{1}, \text { Ravi Prasad Hegde }}{ }^{2}$, Smitha $\mathrm{K}^{3}$, Vinitha D'souza ${ }^{4}$
}

${ }^{1}$ Final year PG Scholar, ${ }^{2}$ Assistant Professor, ${ }^{3}$ Assistant Professor, ${ }^{4}$ Assistant Professor, Dept. of Manovijnana Evam Manasa roga, Alva's Ayurveda Medical College, Moodbidri, Dakshina Kannada Dist. Karnataka, India ${ }^{4}$

Corresponding Author: pramodbhovi@gmail.com

https://doi.org/10.46607/iamj1608092020

(Published online: September 2020)

Open Access

(C) International Ayurvedic Medical Journal, India 2020

Article Received: 31/08/2020 - Peer Reviewed: 08/09/2020 - Accepted for Publication: 08/09/2020

Check for updates

\section{ABSTRACT}

Depression is a common but serious mood disorder which exerts wide range of physical, physiological and psychological impact. It may include feeling of anxiety, sadness, emptiness, helplessness, worthlessness, guilty, irritability or restlessness. According to WHO (2017, p.1), Depression affected over 322 million people worldwide as per 2015 statistics. In India it is estimated that around 57 million people are affected by depression. Vishada is the main factor which increases the range of all the diseases. It is a condition originated from apprehension of failure, resulting in incapability of mind and body to function normally with significant reduction in activities. When depression compared with Vishada, symptoms appears similar hence we can co-relate Vishada with depression. Samanya Unmada Chikitsa can be used in all kind of Manasikarogas based on the understanding of the Doshas predominant in that particular condition. In Chikitsa sangraha, Chakradatta mentions Sarshapa taila Nasya in Unmada chikitsa. Sarshapa Taila having Ushna and Teekshna qualities that can subside VataKapha Dosha. Vishada is one of the Vataja vikara and Nasya Karma is considered as prime line of treatment in Vataja Vikaras and could effective, economical and affordable treatment modality. The drug is having Snigdha Guna which is easily administrable Hence the study was planned to check efficacy of Sarshapa Taila in Vishada.

Keywords: Vishada, Nasya, Sarshapa Taila 


\section{INTRODUCTION}

Depression it is mood disorder. In our day to day activities everyone occasionally feels sad, but these feelings are usually pass within a couple of days. When a person has a depressive disorder, it interferes with their daily life, normal functions, and it causes pain for both the person with the disorder and those who care about him or her. Depression is a common but serious illness, and anyone who experiences it need treatment to get better. Vishada is one of the Vata Nanatmaja vikaras and one of the ManasikaRoga ${ }^{l}$ described in Ayurvedic literature. This disease has manifestations of loss of interest and inactivity in routine works following fear of failure. The symptoms of Vishada resemble disease mild depression in presentation. In depression the mood or effect of an individual are derailed. This disease is characterised by mood of extra ordinary sadness and dejection characterised by depressed mood, pessimistic thinking, reduced energy and psychomotor retardation. In Ayurveda Samanya Unmada Chikitsa can be used in all kind of Manasika Rogas. Based on the understanding of the Doshas predominant in that particular condition. Vishada is one among the Vataja Vikaras and Nasya karma is consider as one of the prime treatment modalities in treating Vatavyadhi. However, Sushrutha Samhita mentioned Sarshapa Taila Nasya as ShodhanaNasya ${ }^{2}$ and Chakradatta mention Sarshapa Taila Nasya for Unmada Sarshapa Taila having Ushna and Teekshna qualities that can subside Vatakapha dosha ${ }^{3}$. This drug is having Sneha Guna which is best medicine for Vata Dosha and easily administrable without much hospitalization. Hence the study is intended to find the effect of Sarshapa Taila Nasya in Vishada.

\section{Aim and Objectives}

To evaluate the efficacy of Sarshapa Taila Nasya in the management of Vishada.

\section{Materials and Methods}

\section{Selection of cases}

20 Patients attending the OPD and IPD department of Manasa Roga, Alva`s Ayurvedic Medical college and Hospital, Moodbidri. Diagnosed with depression and willing patients were enrolled in the study Case selection was random regardless of age, sex, occupation and socioeconomic considerations.

\section{Ethical clearance}

The institutional Ethical Committee of the Alvas Ayurveda Medical College and Hospital, Moodbodri, Dakshina Kannada, Karnataka, approved the study. An informed written consent was taken from each willing patient. The patients were free to withdraw their name from the study at any time without giving any reason.

\section{Inclusion Criteria:}

1. Patients diagnosed as per the criteria for mild and moderate depression as per ICD -10 .

2. Age between 16 to 60 years.

3. Nasyarha patients.

4. Patients of either gender, irrespective of socio-economic status.

\section{Exclusion Criteria:}

1. Patients with frequent suicidal tendency/ thoughts.

2. Patients with major depressive disorder.

3. Pregnant women/ Lactating women.

4. Patients with other psychiatric disorders.

\section{Procedure}

\section{Study Design:}

Single group clinical study.

\begin{tabular}{|l|l|l|l|}
\hline Drug & Mode of Administration & Dose & Duration of Treatment \\
\hline Sarshapa Taila & Nasya & 6 Bindu In Each Nostril. & 1 Sitting For 7days \\
\hline
\end{tabular}

Observation Period: Patients were observed before the treatment and on $7^{\text {th }}$ day (after treatment).

Study Duration -14 Days.

Follow up period: Follow up was done on 14th day.

\section{Assessment Criteria:}

Subjects were assessed by using Hamilton's Depression Rating Scale ${ }^{4}$. 


\section{Diagnostic Criteria:}

ICD 10 Criteria.

\section{Statistical test}

The obtained data on the basis of observations was subjected to statistical analysis in terms of mean, standard deviation, and standard error by applying student ' $t$ ' test. The results were interpreted at the level of $P<0.001$ as highly significant, $P<0.05$ or $P<0.01$ as significant and $P<0.10$ or $P>0.01$ as insignificant.

\section{Results}

The effect of therapy is shown in Table 1 and overall effect of the group is shown in Table 2

\section{Observation:}

Gender: Majority of patients i.e. 75\% were male, $25 \%$ were Female. Though incidence of depression is more in females, in this study male patients approached more for the study.

Age: Among 20 subjects $30 \%$ were belong to age group 16-30 years of age group, followed by $67.5 \%$ in age group of $31-50$, Remaining $2.5 \%$ were belong to age group of 51-70 years. Among 40 subjects participated in the study maximum no of subjects belonged to the age group $67.5 \%$ due to Prevalence of depression is more in this group.

Religion: It was observed in the study that $90 \%$ were Hindu, 5\% were Christian and 5\% were Muslim. This is due to the predominance of Hindu population in the area.

Marital Status: Majority of patients i.e. $65 \%$ were married and $14 \%$ were unmarried the age group selected for the study was 16-60 years and the incidence of middle-aged population was more, hence majority are married.
Education: $10 \%$ were had primary education, $67.5 \%$ were Higher Secondary and 22.5\% were Graduates. It indicates the educational status of the region.

Occupation: $12.5 \%$ were Housewife, 20\% Students and $27.5 \%$ Business class, $17.5 \%$ Agriculturists, $22.5 \%$ Service class. Business class people more suffer more due to work related problems.

Socio-economic status: Majority of patients belonged to middle class, i.e. $67.5 \%$., $32 \%$ were from Lower Middle Class. It shows middle class people suffer more of stress related issues.

Diet: $70 \%$ of patients were consuming mixed diet and $30 \%$ were vegetarians According to recent researches, non-vegetarians (Mixed) suffer more from anxiety, stress which lead to depression.

Prakruti: Majority of patients belonged to 52.5\% Vatakapha Prakruti, 32.5\% had Vata-Pitta Prakruti, 15\% had Pitta-Kapha Prakruti, Due to Vata Kapha Doshas are predominant Doshas in Vishada.

Satva: $67.5 \%$ of patients were of Madhyama Satva, 32.5\% Avara Satva.

Manasika Prakruti: Majority of the patients were of 57.5\% Rajasika Prakruti, 42.5\% had Tamasika Prakruti. Vishada is a Vataja Nanatmaja Vikara which increased Rajo Guna of manas.

Kosta: As per the study, it is observed that $82.5 \%$ were KruraKoshta, 17.5\% were Madhyama Koshta, this might be because of Agnimandya.

Agni: $67.5 \%$ patients were of Mandagni, 12.5\% had Teekshnagni, 5\% had Vishamagni and 15\% had $S a-$ magni. This shows the relation between disease and $\mathrm{Ag}$ nimandya.

Table 1: Effect of Sarshapa Taila Nasya on Symptoms

\begin{tabular}{|l|l|l|l|l|l|l|l|}
\hline Symptoms & BT & AT & RELIEF\% & SD & SE & t - Value & p - Value \\
\hline Loss of interest in activity & 2.00 & 0.70 & 69 & 0.47 & 0.15 & 12.36 & $<0.001$ \\
\hline Decreased energy & 2.00 & 0.70 & 65 & 0.47 & 0.10 & 12.36 & $<0.001$ \\
\hline Loss of self confidence & 2.00 & 0.60 & 70.5 & 0.50 & 0.11 & 12.45 & $<0.001$ \\
\hline Unreasonable guilt & 1.90 & 0.7 & 63.1 & 0.52 & 0.11 & 10.25 & $<0.001$ \\
\hline Suicidal thoughts & 0.2 & 00 & 75 & 0.61 & 0.13 & 11.45 & $<0.001$ \\
\hline Difficulty in concentration & 2.0 & 0.60 & 70 & 0.50 & 0.11 & 12.45 & $<0.001$ \\
\hline Change in psychomotor activity & 1.8 & 0.70 & 65.1 & 0.55 & 0.12 & 8.90 & $<0.001$ \\
\hline
\end{tabular}




\begin{tabular}{|l|l|l|l|l|l|l|l|}
\hline Sleep disturbance & 2.0 & 0.70 & 65 & 0.47 & 0.10 & 12.36 & $<0.001$ \\
\hline Variations in appetite & 1.20 & 0.45 & 62 & 0.85 & 0.19 & 13.94 & $<0.001$ \\
\hline HDR Scale & 19.4 & 16.10 & 30.9 & 0.86 & 0.19 & 12.07 & $<0.001$ \\
\hline
\end{tabular}

Table 2: Overall effect of Sarshapa Taila Nasya

\begin{tabular}{|l|l|c|}
\hline Overall Effect of The Group & Grading & Number of Subjects \\
\hline Class & No Change & 0 \\
\hline$<25 \%$ & Mild Improvement & 1 \\
\hline $51-75 \%$ & Moderate Improvement & 17 \\
\hline$>75$ & Marked Improvement & 2 \\
\hline
\end{tabular}

\section{DISCUSSION}

\section{Discussion on symptoms:}

The pre and post treatment observations were recorded, and the student ' $t$ ' test was done to find out the statistical significance. Regarding the response of the treatment on symptoms in the patients treated with Sarshapa Taila Nasya showed good effect on all symptoms. Sarshapa Taila contains Omega 3 fatty acids, Monounsaturated fatty acids, Glucosinolates, VitaminE and Antioxidants. Omega-3 fatty acid deficiency leads to depression by hampering serotonin production. Serotonin is chemical neurotransmitter, which helps to regulate positive mood, social behavior, appetite, sleep, memory etc ${ }^{5}$. The Kapha and Vata are the predominant Doshas in Vishada ${ }^{6}$. Sarshapa Taila is having Katu Tikta rasa, Agni Deepaka, Srotoshodhaka properties and Ushna and Teekshna qualities that can subside Vata Kapha Dosha ${ }^{7}$ so Sarshapa Taila is beneficial for Vishada condition. Antioxidant property which acts as Rasayana. The Srotoshodhaka action of the drug helps to act deeply on the mind destructing the Avarana of Tamas. It also acts in normalizing the chemical changes in brain by balancing the neurotransmitters so There is significant effect of Sarshapa Taila Nasya is seen in Vishada. Hamilton's Depression Rating Scale shows In $30.9 \%$ were improved after treatment. Result showed that Sarshapa Taila Nasya effective in Vishada.

Discussion on Nasya: The nose is the gateway of drug administration in case of Urdhwajatrugata Rogas and Nasya is the only procedure which directly influences all Indriyas. The drug administered through nose as Nasya reaches to the brain and eliminates all the morbid Doshas responsible for producing disease.
Vishada is a Manasika Vikara in which there is TamoAvarana. And Shiras is considered as one of the Sthanas of Manas. According to references nose is the gateway to skull and Nasya is the best therapeutic procedure for removing morbid Doshas from the Uttamanga ${ }^{7}$.

\section{CONCLUSION}

Sarshapa Taila Nasya is effective formulation giving good result in the management of Vishada due to its Ushna, Tikshna Guna, Agnideepaka and Srotoshodaka properties. Nasya expels the Utklishta doshas with minimal therapeutic dose there by shows quick results. The Group showing highly significant result.

\section{REFERENCES}

1. Acharya susharutha, Sushruta samhita, Hindi commentary Edited by Kaviraj Dr. Ambikadatta Shastri; Publish by Chaukambha sanskrit samstana edition 2011, Varanasi.pp 702, page no.587.

2. Acharya Susharutha, Sushurta Samhita, Nibandha Sangraha commentary Chaukhambha Orientalia Varanasi, 2002. Sutra Sthana $1 / 24$.

3. Cakradatta, chikitsa sangraha of chakrapani, commentary by G.Prabhaker rao,chapter 20 Page no 194195,sloka no 7-8.

4. Kaplan, Harold I, Sadock BJ. 6th ed. Baltimore, Maryland, U.S.A.: Willium and wilkins; 1991. Synopsis of Psychiatry. [Google Scholar]

5. https://www.easyayurveda.com/2015/03/19/mustardbenefits-types-side-effects-research/

6. Acharya Susharutha, Sushurta Samhita, Nibandha Sangraha commentary Chaukhambha Orientalia Varanasi, 2002, Chikitsa Sthana. 40/34. 
7. Dravya Guna Vijanana Hindi commentary by Prof Priyavrata Sharma Chaukhambha VisvaBharati Publication, 2012.Page no:152-154.

\section{Source of Support: Nil \\ Conflict of Interest: None Declared}

How to cite this URL: Pramod Bhovi et al: A Clinical Study To Evaluate The Efficacy Of Nasya With Sarshapataila In Vishada (Depression). International Ayurvedic Medical Journal \{online\} 2020 \{cited September, 2020\} Available from: http://www.iamj.in/posts/images/upload/4397 4401.pdf 